Chekanova I. V., Vovk O. Yu., Malakhov S. S., Dubina S. O. Morphometric characteristics of latitude parameters of the middle cranial fossa of mature age human depending on extreme type of skull structure. Journal of Education, Health and Sport. 2021;11(03): 138-146. eISSN 2391-8306. DOI http://dx.doi.org/10.12775/JEHS.2021.11.03.014

https://apcz.umk.pl/czasopisma/index.php/JEHS/article/view/JEHS.2021.11.03.014

https://zenodo.org/record/4658925

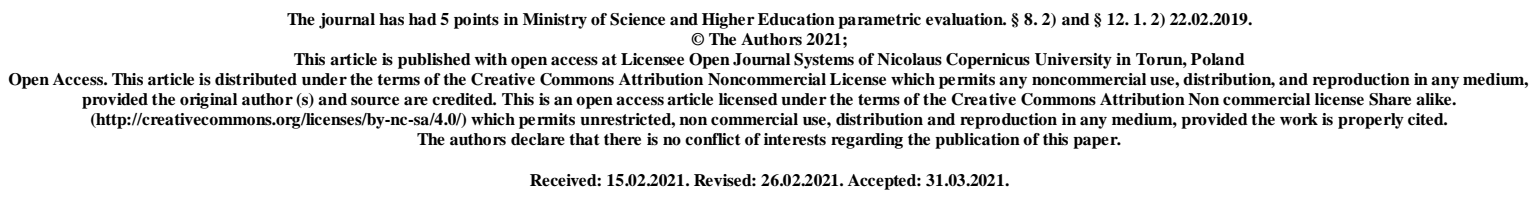

UDC: 611.714.06-053.8:572.73

\title{
MORPHOMETRIC CHARACTERISTICS OF LATITUDE PARAMETERS OF THE MIDDLE CRANIAL FOSSA OF MATURE AGE HUMAN DEPENDING ON EXTREME TYPE OF SKULL STRUCTURE
}

\author{
*I. V. Chekanova, *O. Yu. Vovk, *S. S. Malakhov, **S. O. Dubina \\ *Kharkov National Medical University, Kharkiv, Ukraine \\ **Donetsk National Medical University, Kramatorsk, Ukraine
}

\begin{abstract}
The study of the structure, shape and size of the skull and its individual structures is in great demand not only from the point of view of expansion of knowledge of craniology, but also modern practical medicine. This is due to the rapid development of new methods for diagnosing pathological processes and the development of less traumatic methods of surgical treatment. The purpose of this study is to establish the size of the transverse parameters of the middle cranial fossa of a mature person depending on the three extreme types of skull. The research was conducted using a study of 50 craniotomograms and 50 bone preparations of the skull of men and women of mature age. The studied material was divided into three groups from the standpoint of studying individual anatomical variability. In order to achieve the goal of the study, the transverse parameters of the middle cranial fossa of mature people at different levels and from both halves were measured. The established indicators of transverse dimensions show that all latitudinal parameters tend to increase from the anterior parts of the middle cranial fossa to the posterior parts. The results of the study also show that the total
\end{abstract}


latitudes and transverse dimensions of the left and right parts of the middle cranial fossa predominate in brachicrans and gradually decrease to dolichocrans with average values in mesocrans. This coincides with the fact that the brachycrane has a short and wide skull shape, the dolichocrane has an elongated and narrow one, and the mesocrane has average skull length and width values. The results of this study significantly supplement the existing information on the individual anatomical variability of the middle cranial fossa of a mature person and also allow more detailed application of these data in practical medicine.

Keywords: middle cranial fossa; adulthood; individual anatomical variability; craniometry.

This work is carried out in accordance with the thematic plan of scientific researches of the department of human anatomy of Kharkiv National Medical University "Individual anatomical variability of craniotopographic features and spatial relationships of human head areas in postembryonic period of ontogenesis", state registration number is $0118 U 000954$.

Introduction. Individual anatomical variability remains a relevant problem for anatomic scientists for quite a long time [1-3]. The study of the structure, forms and sizes of the skull and its individual structures are of great demand not only in view of the expansion of craniology knowledge, but also for modern practical medicine [4-9]. This is due to the rapid development of new methods of pathological processes diagnostics and the development of less traumatic methods of surgical treatment [10-14]. In this regard more detailed study of an individual anatomical variability of the middle cranial fossa (MCF) taking into account craniotypes, will make it possible to expand the limits of modern medicine development.

The aim of this study is to establish the dimensions of the transverse parameters of MCF of mature age human depending on three extreme types of skulls.

Materials and methods of the study. The research was carried out by studying 50 craniotomograms and 50 bone preparations of mature age male and female skulls.

Craniometric study of MCF on CT images of mature age human heads was carried out using Anatomage Table anatomy visualization system with Launching Table 6.0 Application setting. Morphometry of latitude parameters of MCF on bone preparations of the human skull was carried out according to standard craniological technique using a generally accepted set of measuring instruments.

In order to achieve the aim of the study, the transverse parameters of MCF of mature people at different levels and both of halves were measured (fig. 1.), namely: total width through the center of the Turkish saddle (TS) $\left(\mathrm{A}_{1}\right)$ is the distance between the parietal edges 
of the scales of both temporal bones through the center of the Turkish saddle; total width at the level of the TS tubercle (A2) - distance between opposite points of side skull walls at the level of TS tubercle; front width of $\operatorname{MCF}\left(a_{1}\right)$, being the dimension between the outer edge of the opening of the visual channel to the opposite point of the side wall of the skull; width on the level of TS tubercle $\left(a_{2}\right)$ is the distance from TS tubercle to the opposite point of the side wall of the skull; rear width of MCF $\left(a_{3}\right)$, which was measured at the level of the back of the Turkish saddle to the opposite points of the side wall of the skull.
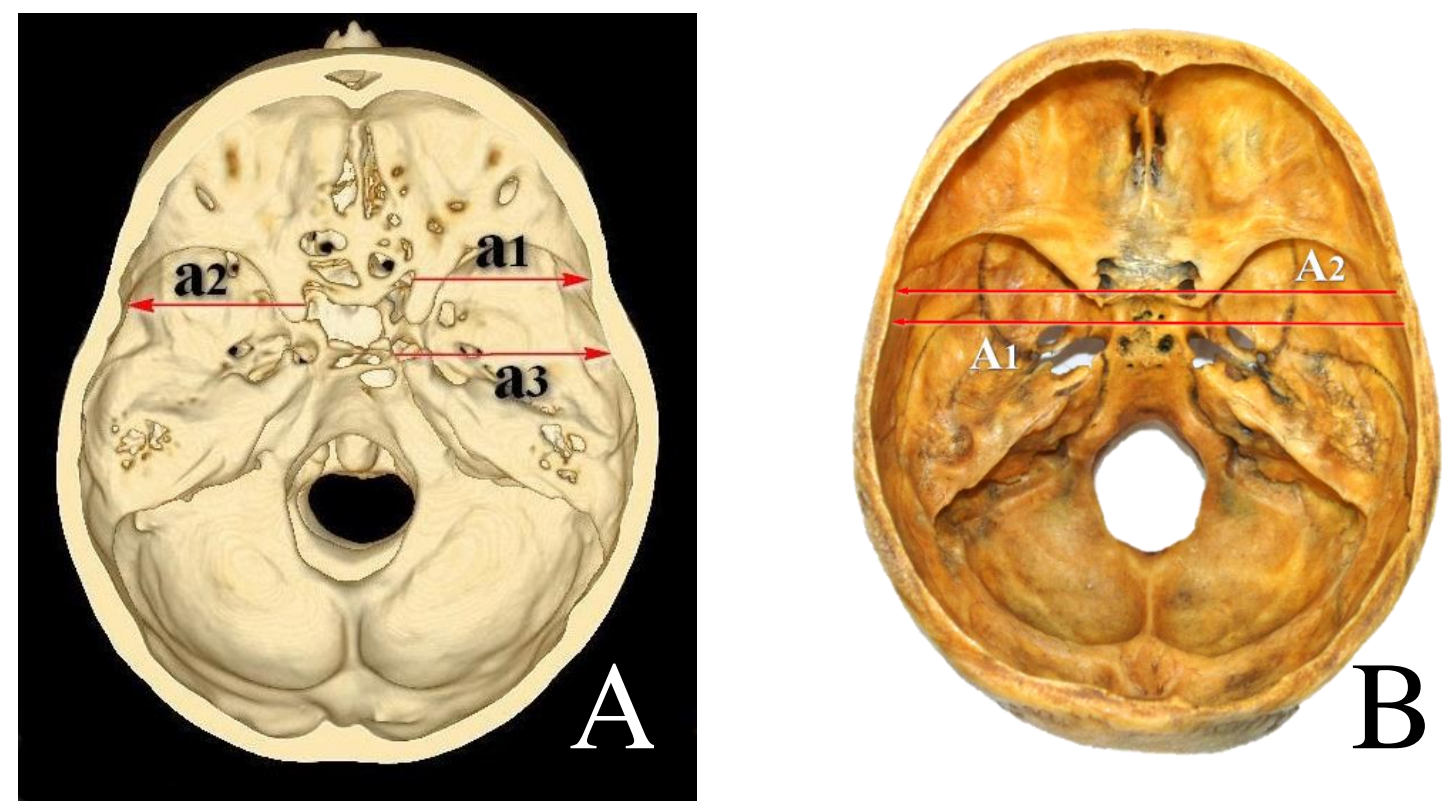

Fig. 1. A - on bones preparations; B - of CT images. Determination of MCF distances in width: A - general width on bones preparations; $\mathbf{B}$ - width distances from left and right halves of MCF on CT images

The investigated material was distributed into three groups from the position of individual anatomical variability study. The largest group consisted of a brachicephalic type of skull and the smallest - dolichocephalic.

The statistical processing of the received results of the study was performed using the SPSS 7.0 applications packets and Excel application from the MS Office XP package. The assessment of the statistical significance of the received data was obtained according to the Mana-Whitney criterion. The results of the comparison were considered reliable at $p \leq 0,05$.

The results of the study and their discussion. Morphometry of the total width through the center of TS in mature people used in determining the general MCF index and the total width at the level of the TS tubercle showed a certain range of variability depending on the extreme types of skulls (table. 1). 
Table 1 - Variation-statistic indices of MCF of mature age human general widths dimensions (in $\mathrm{mm}$ )

\begin{tabular}{|c|c|c|c|c|c|}
\hline Shape of the skull signs & $\min$ & $\max$ & $\mathrm{x} ;^{-}$ & $\sigma$ & $\mathrm{m}$ \\
\hline \multicolumn{7}{|c|}{ General width through the center of TS } \\
\hline Brachicrans & 105,0 & 134,0 & 120,11 & 5,656 & 0,749 \\
\hline Mesocrans & 108,0 & 131,0 & 117,98 & 6,431 & 1,155 \\
\hline Dolichocrans & 111,0 & 122,5 & 116,02 & 3,999 & 1,206 \\
\hline \multicolumn{7}{|c|}{ Genel width on the level of TS tubercle } \\
\hline Brachicrans & 102,4 & 133,9 & 118,72 & 6,555 & 1,141 \\
\hline Mesocrans & 103,2 & 124,9 & 114,85 & 8,775 & 2,533 \\
\hline Dolichocrans & 103,3 & 120,0 & 110,58 & 6,327 & 2,829 \\
\hline
\end{tabular}

It has been found that the general width through the center of TS in mature people with brachicanial type of skull is within the limits $x ;^{-} \pm \sigma=120,11 \pm 5,656 \mathrm{~mm}$. In mesocrans and dolichocrans, the specified size is slightly decreasing and comprises $x ;^{-} \pm \sigma=$ $117,98 \pm 6,431 \mathrm{~mm}$ and $\mathrm{x} ;{ }^{-} \pm \sigma=116,02 \pm 3,999 \mathrm{~mm}$ consequently.

Along with this it was determined that the same tendency is seen among the people of the same age as in general width of TS tubercles level: in brachiocephales it has maximal meanings reaching $x ;^{-} \pm \sigma=118,72 \pm 6,555 \mathrm{~mm}$; in mesocrans $-\mathrm{x} ;^{-} \pm \sigma=114,85 \pm 8,775 \mathrm{~mm}$ and in dolichocrans minimal meanings are found $-\mathrm{x} ;^{-} \pm \sigma=110,58 \pm 6,327 \mathrm{~mm}$.

Similarly, the variability of the latitudinal sizes of the left and right halves of MCF of mature age people at different levels, taking into account the extreme types of skulls, was established. (table. 2.).

According to the received data the front width in brachiocephales from the left of $\mathrm{MCF}$ is $\mathrm{x} ;^{-} \pm \sigma=40,88 \pm 2,573 \mathrm{~mm}$ and from the right $-\mathrm{x} ;^{-} \pm \sigma=41,73 \pm 3,266 \mathrm{~mm}$. Wherein in mesocrans the given transverse size has statistical indices within the framework $\mathrm{x} ;^{-} \pm \sigma=$ $40,14 \pm 3,853 \mathrm{~mm}$ on the left and $\mathrm{x} ;{ }^{-} \pm \sigma=40,47 \pm 3,758 \mathrm{~mm}$ on the right. In people of mature age with dolichocranic type of the skull the parameter $a_{1}$ in left and right areas of the studied part of the skull has minimal meaning and comprises $\mathrm{x} ;^{-} \pm \sigma=38,54 \pm 2,409 \mathrm{~mm}$ and $\mathrm{x} ;{ }^{-} \pm \sigma=$ $39,16 \pm 2,001 \mathrm{~mm}$ consequently.

During morphometry of the width in mature people at the level of TS it was found that from the left half of MCF this parameter varies within the limits $x ;^{-} \pm \sigma=47,49 \pm 3,403 \mathrm{~mm}$ in brachicrans, $x ;^{-} \pm \sigma=45,78 \pm 4,300 \mathrm{~mm}$ - in mesocrans and in dolichocrans it does not exceed $\mathrm{x} ;{ }^{-} \pm \sigma=44,26 \pm 2,702 \mathrm{~mm}$. At the same time, from the right half the size $\mathrm{a}_{2}$ takes the maximum values in mature people with a brachicephalic type of the skull structure $\left(x ;^{-} \pm \sigma=\right.$ 
$48,32 \pm 3,294 \mathrm{~mm})$; medium - mesocephalic $\left(x ;^{-} \pm \sigma=46,81 \pm 3,897 \mathrm{~mm}\right)$ and the smallest size is typical for dolichocephalic form $\left(x ;^{-} \pm \sigma=45,84 \pm 3,819 \mathrm{~mm}\right)$.

Table 2 - Variation-statistic indices of the width parameters from MCF both sides of mature age human (in $\mathrm{mm}$ )

\begin{tabular}{|c|c|c|c|c|c|c|}
\hline Shape of the sku & dies signs & $\min$ & $\max$ & $\mathrm{x} ;^{-}$ & $\sigma$ & $\mathrm{m}$ \\
\hline \multicolumn{7}{|c|}{ Front width of MCF } \\
\hline \multirow{2}{*}{ Brachicrans } & Left & 36,0 & 47,7 & 40,88 & 2,573 & 0,364 \\
\hline & Right & 36,0 & 51,3 & 41,73 & 3,266 & 0,462 \\
\hline \multirow{2}{*}{ Mesocrans } & Left & 34,7 & 49,3 & 40,14 & 3,853 & 0,703 \\
\hline & Right & 35,0 & 47,5 & 40,47 & 3,758 & 0,675 \\
\hline \multirow{2}{*}{ Dolichocrans } & Left & 34,0 & 42,0 & 38,54 & 2,409 & 0,695 \\
\hline & Right & 35,1 & 41,0 & 39,16 & 2,001 & 0,578 \\
\hline \multicolumn{7}{|c|}{ Width on the level of TS tubercle } \\
\hline \multirow{2}{*}{ Brachicrans } & Left & 39,7 & 54,8 & 47,49 & 3,403 & 0,592 \\
\hline & Right & 40,6 & 54,6 & 48,32 & 3,294 & 0,573 \\
\hline \multirow{2}{*}{ Mesocrans } & Left & 39,2 & 51,8 & 45,78 & 4,300 & 1,241 \\
\hline & Right. & 39,1 & 51,4 & 46,81 & 3,897 & 1,125 \\
\hline \multirow{2}{*}{ Dolichocrans } & Left & 42,0 & 47,3 & 44,26 & 2,702 & 1,209 \\
\hline & Right & 40,0 & 50,7 & 45,84 & 3,819 & 1,708 \\
\hline \multicolumn{7}{|c|}{ Width on the level of TS back } \\
\hline \multirow{2}{*}{ Brachicrans } & Left & 45,0 & 59,0 & 52,19 & 3,745 & 0,496 \\
\hline & Right & 45,0 & 59,2 & 52,87 & 3,095 & 0,410 \\
\hline \multirow{2}{*}{ Mesocrans } & Left & 45,0 & 59,0 & 50,34 & 4,236 & 0,761 \\
\hline & Right & 45,0 & 62,0 & 51,85 & 3,819 & 0,686 \\
\hline \multirow{2}{*}{ Dolichocrans } & Left & 42,0 & 54,6 & 49,45 & 3,689 & 1,065 \\
\hline & Right & 43,0 & 55,0 & 50,82 & 3,741 & 1,128 \\
\hline
\end{tabular}

A similar tendency is stored in determining the width at the level of the TS back from both sections of MCF. Thus, in mature brachicephals the size $\mathrm{a}_{3}$ from the left is $x ;^{-} \pm \sigma=$ $52,19 \pm 3,745 \mathrm{~mm}$ and from the right $-\mathrm{x} ;^{-} \pm \sigma=52,87 \pm 3,095 \mathrm{~mm}$. In mesocranes the rear width takes average values and comprises $x ;^{-} \pm \sigma=50,34 \pm 4,236 \mathrm{~mm}$ (left) and $\mathrm{x} ;^{-} \pm \sigma=51,85 \pm 3,819$ $\mathrm{mm}$ (right). At the same time, in mature people with a dolichocranic type of the skull structure this parameter from the left and right halves of MCF does not exceed $x ;^{-} \pm \sigma=$ $49,45 \pm 3,689 \mathrm{~mm}$ and $\mathrm{x} ;^{-} \pm \sigma=50,82 \pm 3,741 \mathrm{~mm}$ consequently.

The determined indices of latitude size show that all longitudinal parameters have the tendency to increase from front areas of MCF to the rear (fig. 2). 

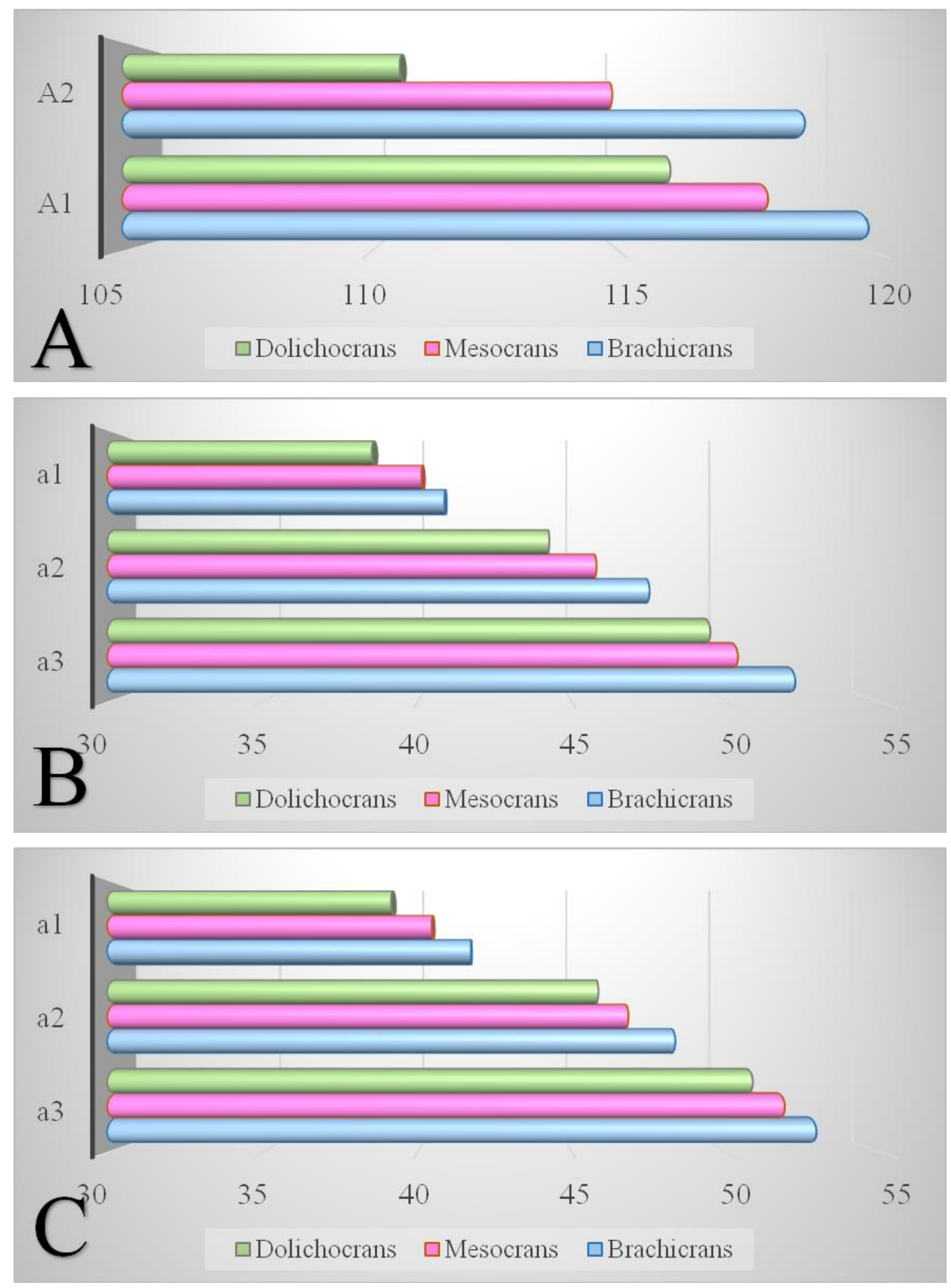

Fig. 2. The differences range of transverse parameters of MCF in people of mature age depending on the extreme types of the skull structure: $\mathbf{A}$ - general; $\mathbf{B}$ - on the left; $\mathbf{C}$ - on the right. 
The results of the study also show that general latitudes and transverse dimensions from the left and right parts of MCF dominate just in brachicephals and gradually decrease to dolichocephales with average meanings in mesocephales (Fig. 3). This entirely coincides with the fact that in brachicrans, the form of the skull is short and wide, in the dolichocrans elongated and narrow, and in mesocrans the length and width of the skull have average values.

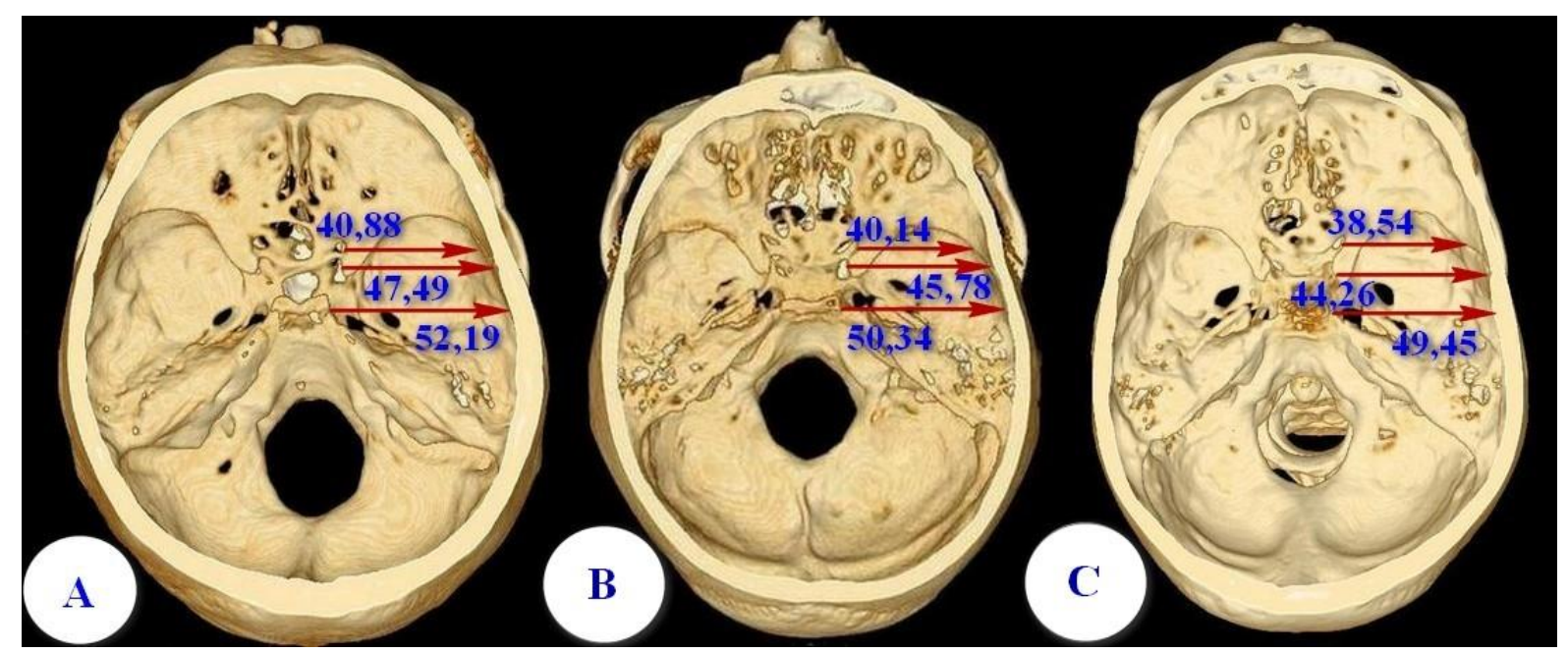

Fig. 3. Average meanings of latitudinal size of MCF on CT images of human head of mature age person depending on the extreme types of the skull: $\mathbf{A}$ - brachicrans; $\mathbf{B}$ mesocrans; $\mathbf{C}$ - dolichocrans.

\section{Conclusions}

During the study of cross-sectional parameters of MCF of the mature age human, it was found that the size of the width becomes minimal in dolichocephales and maximal in brachicephals. In people with mesocranial type of the skulls average values of MCF crosssectional parameters are determined. Morphometry also showed a decrease in latitudinal sizes in the front and increase - in the rear parts of the MCF of the mature age human.

Perspectives of further studies. The results of this study significantly complete the existing information about the individual anatomical variability of MCF of mature age human and also make it possible to use these data in practical medicine in details and more widely .

\section{References}

1. Vovk Yu.N., Bekov D.B. Individualnaya anatomicheskaya izmenchivost i anatomicheskaya norma stroeniya cheloveka. [Individual anatomical variability and 
anatomical norm of the human structure] Zbir. «Problemi ekologichnoyi ta medichnoyi genetiki i klinichnoyi imunologiyi». Kiyiv-Lugansk-Harkiv. 2001;7 (39):81-89. Russian

2. Gajvoronskij I.V., Bajbakov S.E. Individualnaya anatomicheskaya izmenchivost: istoriko-metodologicheskie aspekty izucheniya. [Individual anatomical variability: historical and methodological aspects of the study] Vestnik eksperimentalnoj $i$ klinicheskoj hirurgii. 2008;1(1):62-69. Russian

3. D'yachenko A.P., Fominyh T.A., CHalbash D.A-R. Individual'naya anatomicheskaya izmenchivost' i anatomiya identichnyh ob"ektov. [Individual anatomical variability and anatomy of identical objects] Ukraïns'kij morfologichnij al'manah. 2011;9(3):103-105. Russian

4. Babych L.V. Osoblyvosti kompiuterno-tomohrafichnykh rozmiriv serednoi cherepnoi yamky v zdorovykh yunakiv i divchat riznykh somatotypiv. [Features of computed tomography of the middle cranial fossa in healthy boys and girls of different somatotypes] Visnyk Vinnytskoho natsionalnoho medychnoho universytetu. 2013; 17(2):306-310. Ukrainian

5. Bekov D.B. Izuchenie individualnoj anatomicheskoj izmenchivosti — odna iz zadach sovremennoj morfologii. [The study of individual anatomical variability is one of the tasks of modern morphology] AGE. 1991;10(7):85-88. Russian

6. Vovk Yu.N., Vovk O.Yu. Perspektivy i novye napravleniya ucheniya ob individualnoj anatomicheskoj izmenchivosti. [Prospects and new directions in the study of individual anatomical variability] Visnik problem biologiyi $i$ medicini. 2016;2,1(128):376379. Russian

7. Bekelis K, Moses Z, Missios S, Saunders J, Erkmen K. Middle cranial fossa approach: pathologies and complications. J Neurol Surg B. 2012;73:A209. DOI: 10.1055/s0032-1312257

8. Kizilkanat E.D., Boyan N, Tekdemir I, Soames R, Oguz O. Surgical importance of the morphometry of the anterior and middle cranial fossae. Neurosurgery Quarterly. 2007;17(1):60-63.

9. Gökce C., Cicekcibasi A.E., Yilmaz M.T., Kiresi D. The morphometrıc analysis of the important bone structures on skull base in living individuals with multidetector computed tomography. Int. J. Morphol. 2014;32(3):812-821.

10. Kambiev R.L. Endoskopicheskaya assistenciya pri cerebralnyh nejrohirurgicheskih dostupah [Endoscopic assistance with cerebral neurosurgical approaches] [dysertatsiia]. Ros. med. akad. poslediplom. obrazovan SPb.; 2016. 21 c. Russian 
11. Acharya AN., Rajan GP. Piezosurgery for the repair of middle cranial fossa meningoencephaloceles. Otol Neurotol. 2015 Mar;36(3):444-7. Doi: 10.1097/MAO.000000000000645

12. Chotai S., Kshettry VR, Petrak A, Ammirati M. Lateral transzygomatic middle fossa approach and its extensions: surgical technique and 3D anatomy. Clin Neurol Neurosurg. 2015 Mar.;130:33-41. Doi: 10.1016/j.clineuro.2014.12.014. Epub 2014 Dec 29.

13. Liming BJ, Westbrook B, Bakken H, Crawford JV. Cadaveric study of an endoscopic keyhole middle fossa craniotomy approach to the superior semicircular canal. Otol Neurotol. 2016 Ju;37(5):533-8. Doi: 10.1097/MAO. 0000000000000995.

14. Roche JP, Woodson EA, Hansen MR, Gantz BJ. Ultra long-term audiometric outcomes in treatment of vestibular shwannoma with the middle cranial fossa approach. Otol Neurotol. 2018 Feb;39(2):e151-e157. Doi: 10.1097/MAO.0000000000001678. 